\title{
Manajemen Stres Menghadapi Covid-19 dalam Pendidikan Islam
}

\author{
Iin Setyani \\ Universitas Ahmad Dahlan \\ iinsetyani92@gmail.com
}

\begin{abstract}
The corona covid-19 virus phenomenon is very shocking the world. Almost all people in the world experience uncertainty and many receive information from social media whose truth is uncertain. This has unwittingly caused panic for some people. The number of hoax news that caused panic and the appeal for social distancing by the government without any proper counseling to the community, which resulted in panic. Not only this it also affects the mental health of a person to unwittingly cause stress. The purpose of this study is to find out how to manage stress in dealing with covid-19 in the perspective of Islamic education. The research approach used is a form of research obtained from the literature in the field of Islamic education and stress management. Data collection techniques by searching related literature both online and offline. Data analysis techniques using data analysis techniques from related literature. The results of research conducted are stress management to deal with covid-19 in Islamic education is to think positively, avoid hoax news, avoid excessive panic, pray and worship Allah, and always pray to Allah.
\end{abstract}

\section{Keywords: Covid-19, Stress Management, Islamic Education.}

\begin{abstract}
Abstrak
Fenomena virus corona Covid-19 sangat menggemparkan dunia. Hampir semua masyarakat di dunia mengalami ketidakpastian dan banyak menerima informasi dari media social yang belum pasti kebenarannya. Hal ini tanpa disadari menyebabkan kepanikan bagi sebagian masyarakat. Banyaknya berita hoax yang menyebabkan kepanikan serta adanya himbauan untuk social distancing oleh pemerintah tanpa ada penyuluhan yang benar kepada masyarakat, yang berakibat kepanikan. Tidak hanya itu hal ini pun berakibat kepada kesehatan mental seseorang hingga tanpa disadari menyebabkan stress. Tujuan penelitian ini adalah menemukan bagaimana memanajemen stres menghadapi covid-19 dalam prespektif pendidikan Islam . Pendekatan penelitian yang digunakan adalah bentuk penelitian yang diperoleh dari literatur-literatur di bidang pendidikan Islam dan manajemen stress. Teknik pengumpulan data dengan penelusuran terhadap literaturliteratur terkait baik secara online maupun offline. Teknik analisis data menggunakan teknik analisis data dari literature terkait. Hasil penelitian yang dilakukan adalah manajemen stress menghadapi Covid-19 dalam pendidikan islam adalah dengan berpikir
\end{abstract}


positif, menghindari berita hoax, menghindari panic yang berlebih, berdoa dan beribadah kepada Allah, dan selalu bertawaqal kepada Allah.

\section{Kata kunci : covid-19, manajemen stress, pendidikan Islam.}

\section{PENDAHULUAN}

Saat ini wabah Covid-19 sangat meresahkan masyarakat dan membuat kepanikan dimanamana. Wabah ini muncul pertama kali di Wuhan, China pada bulan Desember 2019 dan dengan cepat telah menyebar ke berbagai belahan dunia. Wabah Covid-19 ini merupakan wabah yang disebabkan oleh virus yang menyebabkan penyakit pada manusia dan hewan. Covid-19 ini dapat menyebabkan manusia mengalami infeksi pernapasan seperti flu biasa hingga penyakit yang lebis parah seperti Middle Respiratory Syndrome (MERS), dan Severe Acute Respiraratory syndrome (SARS). Wabah Covid-19 dapat menulsr hanya dengan tetesan kecil dari cairan (droplet) yang keluar dari hidung atau mulut penderita yang sedang batuk atau menghembuskan nafas dan secara tidak sengaja mengeluarkan cairan itu. Tetesan itu bisa jatuh ke benda dan disentuh oleh orang lain yang mengakibatkan dapat beresiko tinggi untuk tertular. Hal itu yang menyebabkan pemerintah mengumumkan agar diterapkannya Pembatasan Sosial Berskala Besar (PSBB) yang diharapkan dapat menekan jumlah penularan wabah Covid-19. Wabah ini banyak menyebabkan perubahanperubahan pada masyarakat. Tidak disadari hal itu menimbulkan stres bagi sebagaian orang. Rasa cemas, khawatir, stress ini sering dialami oleh sebagian orang saat mereka dalam kondisi krisis, seperti menghadapi Covid-19 ini yang menyebar diberbagai negara. Wabah ini sangat cepat perkembanganya. Apabila kita lengah sedikit saja akan berdampak besar. Oleh karena itu sangat penting sekali kita melakukan pencegahan seperti isolasi mandiri dan phsycal distancing (jaga jarak fisik). Dan akhirnya pemerintah Indonesia memutuskan untuk menghimbau masyarakat agar di rumah saja dan melakukan phsycal distancing. Menanggapi hal Ini pendidikan Islam melakukan pembelajaran secara daring. Dan tidak boleh ada perkumpulan di sekolah, kampus dan lembaga pendidikan lainnya. Tentu hal ini sangat berpengaruh bagi sebagian orang yang terbiasa bersosialisasi. Mereka akan merasa kesepian, lebih tertekan dan tidak memiliki hubungan sosial. Akibatnya berdampak pada kesehatan jiwa. Bahkan ada beberapa kasus bunuh diri karena Covid-19. Ini disebabkan karena adanya isolasi. Pencegahan bunuh diri biasanya diatasi dengan 
kontak social, sementara ini untuk membatasi penyebaran Covid-19 diterapkan physical distancing. Problematika yang di hadapi dalam pendidikan islam saat ini adalah dampak dari adanya Covid-19 yang membuat sistem pembelajaraan yang biasanya bertatap muka langsung kini lewat online. Ini menimbulkan permasalahan bari bagi sebagian mahasiswa. Ada yang tempat tinggalnya di dalam pelosok jadi sangat susah untuk mendapatkan signal, akhirnya tidak mengikuti pembelajaran secara online. Ini menimbulkan stres bagi sebagian orang karena tidak bisa beraktifitas seperti biasanya lagi. Agar kesehatan jiwa tetap terjaga kita harus menjaga ketenangan batin, tidak panic berlebihan, dan memanajemen stress dengan baik. Stres diketahuai dapat menurunkan imunitas tubuh, padahal untuk menghadapi Covid-19 ini diperlukan kekebalan tubuh yang baik. Untuk menjaga kekebalan tubuh yang baik kita harus dapat mengolah atau memanajemen stress. Stres adalah respon terhadap sesuatu yang dirasakan mengancam kesehatan individu. ${ }^{1}$ Manajemen stres merupakan kemampuan seseorang dalam menangani gangguan mental dan emosional yang disebabkan oleh reaksi tertentu. Stres terjadi jika individu dihadapkan dengan peristiwa yang mereka rasakan sebagai ancaman kesehatan fisik atau psikologis. Suatu Keadaan yang memicu adanya stres disebut stressor dan reaksi yang dihasilkannya disebut respon stres (Manktelow, 2007). ${ }^{2}$ Penelitian tentang stresor mampu mendefinisikan keadaan yang cenderung menyebabkan stres dan tidak menyebabkan stres, tetapi jika hanya berfokus disitu saja tentu tidak dapat menjelaskan bagaimana pengalaman stresitu sendiri. Setiap individu mempunyai pengalaaman stress yang berbeda-beda satu dengan yang lainnya. Setiap individu pun mempunyai respon yang berbeda ketika stress. Respon terhadap stress dapat dilihat dari perubahan fisiologis, emosional, dan perilaku. Hal ini dapat dijadikan acuan untuk mengukur tingkat tiap-tiap individu. Berdasarkan penjelasan ini maka dapat diketahui beberapa gejala stres seperti :

a) Perubahan emosional.

Mulai dari muncul perasaan cemas, perasaan takut, lebih mudah marah, moody, dan perasaan tidak sanggup menghadapinya;

b) Gejala yang muncul dipikiran.

\footnotetext{
${ }^{1}$ Nurleila Jum'ati and Himmayatul Wusma, "Stres Kerja (Occupational Stres) Yang Mempengaruhi Kinerja Individu Pada Dinas Kesehatan Bidang Pencegahan Pemberantasan Penyakit Dan Penyehatan Lingkungan (P2P-PL) Di Kabupaten Bangkalan," Jurnal NeO-Bis 7, no. 2 (2013): 1-17.

${ }^{2}$ Agoes and dkk, Teori Dan Manajemen Stres (Kontemporer Dan Islam) (Malang: Taroda, 2003).
} 
Muncul perasaan rendah diri, perasaan takut gagal, konsentrasi menurun, melakukan tindakan yang memalukan, mulai khawatir akan masa depan, menjadi pelupa, dan emosi naik turun;

c) Perubahan perilaku sosial.

Mulai dari tidak bias bersosialisasi dengan normal, tidak mampu bekerjasama, tidak bisa santai dalam melakukan sesuatu, tiba-tiba menangis tanpa tau apa sebabnyaa, berkelakuan seenaknya sendiri, mudah terkejut, dan tidak napsu makan;

d) Perubahan fisik.

Seperti mudah berkeringat, detak jantung meningkat, suka menggigil, sering gelisah, mulut dan kerongkongan kering , mudah lelah, gangguan saluran kencing, insomnia, gangguan pencernaan, kepala sering sakit, dan leher pegel. ${ }^{3}$

Tujuan penelitian ini adalah bagaimana memanajemen stres menghadapi Covid-19 dalam pendidikan. Pedidikan tidak hanya sekedar pengetahuan dan nilai saja tetapi juga tentang mengoptimalkan peran otak (Suyadi, 2016). ${ }^{4}$ Peran otak berpengaruh pada manajemen stress. Tahapan manajemen stres:

1. Mempelajari dahulu apa itu stress dan sebab-sebabnya, serta berusaha untuk menghindarinya.

2. Mempelajari ketrampilan mengatasi stres

3. Mengaplikasikan keterampilan yang sudah dipelajari untuk mengatasi stress ke diri sendiri. ${ }^{5}$

\section{METODOLOGI PENELITIAN}

Penelitian ini menggunakan metode kualitatif dengan studi kepustakaan. Sumber data berasal dari penelusuran literarur-literatur yang berkaitan yang didapat dari jurnal dan buku tentang Covid-19, manajemen stress, dan pendidikan islam. Teknik pengumpulan data melalui referensi terkait, baik secara offline maupun online. Jurnal didapat dari akses jurnal

\footnotetext{
${ }^{3}$ Agoes and dkk.

${ }^{4}$ Suyadi, Teori Pembelajaran Anak Usia Dini Dalam Kajian Neurosains (Bandung: Rosda Karya, 2016).

${ }^{5}$ Rizky Dianita Segarahayu, "Pengaruh Manajemen Stres Terhadap Penurunan Tingkat Stres Pada Narapidana Di Lpw Malang," Universitas Negeri Malang, 2013, 1-16, http://jurnal-

online.um.ac.id/data/artikel/artikelDEB288149FBAA98C9CB27EB18035D95A.pdf.
} 
cendekia. Data yang didapat kemudian diolah menjadi lebih utuh dan terbaru. Analisis data menggunakan analisis secara langsung lewat literatur-literatur terkait.

\section{HASIL DAN PEMBAHASAN}

\section{Covid-19 dalam Pendidikan Islam}

Adanya wabah Covid-19 ini telah mengubah sistem pembelajaran pendidikan Islam yang awalnya menggunakan sistem pembelajaran secara langsung kini dilakukan secara daring (dalam jaringan). Dengan hal ini ada yang merasa lebih mudah dalam sistem pembelajaran daring dan ada yang merasa keberatan terhadap sistem pembelajaran daring. Tidak hanya itu terkadang muncul masalah baru seperti materi yang disampaikan tidak selesai, tugas yang diberikan oleh dosen sangat banyak. Permasalahan lainnya muncul dari akses internet yang tidak stabil mengakibatkan keterlambatan informasi bagi mahasiswa. Bahkan ada beberapa mahasiwa yang tidak mempunyai akses internet di kampung halamanya dan terpaksa tidak mengikuti pembelajaran dengan sistem daring. Dibalik semua ini tentu ada manfaat yang kita rasakan adalah kita dipaksa untuk bisa menikuti perkembangan zaman. Diera teknologi yang sudah canggih ini kita dituntut untuk bisa menguasai teknologi pembelajaran yang sangat bervariasi menjadikan tantangan baru bagi kita semua. Dengan adanya hal ini nantinya akan ada ide yang lebih bervariasi untuk pembelajaran dalam pendidikan Islam. Covid-19 memang berdampak terhadap pendidikan Islam, tetapi dibalik beberapa dampak yang kurang menyenangan juga ada hikmah yang bisa dijadikan pembelajaran agar pendidikan islam lebih baik lagi kedepannya. Dan dapat membuat sadar bahwa pendidikan Islam harus mengusai kemajuan teknologi yang sudah semakin maju.

\section{Perubahan akibat Covid-19}

Covid-19 menyebabkan banyak perubahan dimasyarakat yang dapat menimbulkan stressor. Perubahan yang mendadak tanpa persiapan menyebabkan kepanikan dan keresahan bagi masyarakat. Hal ini mengakibatkan masyarakat bertindak ceroboh. Serperti fenomena panic buying. Alasan mereka melakukan itu adalah untuk berjagajaga karena timbulnya ketidakpastian sampai kapan diberlakukannya social distancing. Hal tersebut menyebabkan kerugian bagi masyarakat lain yang tidak dapat berbelanja 
dalam skala besar dan menyebabkan kesulitan untuk memenuhi kebutuhannya. Tidak hanya itu harga barang kian naik karena permintaan lebih besar daripada stok yang ada. Perubahan tidak hanya terjadi pada perekonomian masyarakat tetapi juga terjadi pada pelaksanaan kegiatan peribadahan. Hal ini membuat syok bagi sebagian masyarakat. Dimulai tidak diperbolehkannya sholat jumat secara berjamaah, sholat fardhu secara berjamaan, kajian-kajian secara langsung. Banyak masyarakat mengangap pemerintah melarang untuk beribadah, kebanyakan dari mereka tidak paham bahaya dari Covid-19 sehingga mereka bersikap seperti itu. Apalagi wabah Covid-19 menyebar hingga bulan ramadhan tiba. Bulan ramadhan merupakan bulan yang sangat ditunggu-tunggu oleh umat islam karena bulan ramadhan merupakan bulan yang mempunyai kemuliaan. Shalat tarawih merupaka sholat sunah yang hanya dikerjakan pada saat bulan ramadhan tetapi dikarenakan adanya Covid-19 pemerintah melarang adanya shalat tarawih secara berjamaah di Masjid. Pemerintah menganjurkan untuk shalat tarawih berjamaah di rumah saja dengan keluarganya. Perubahan juga terjadi pada sistem pendidikan di Indonesia. Sistem yang diberlakukan saat pandemic ini adalah sistem pembelajaran secara daring. Mulai dari TK hingga perguruan tinggi menerapkan sistem pembelajaran secara daring. Tetapi karena banyak masyarakat yang belum siap dengan adanya sistem daring. Selain itu tidak semua masyarakat dapat mengakses internet dengan mudah menyebabkan tidak berjalanya sistem pembeljaran secara daring dengan lancar. Kebanyakan masyaralat mengeluhkan bahwa sistem pembelajran tidak sesuai dengan protokol yang ada karena guru hanya memberikan tugas saja. Mengakibatkan semakin banyaknya pemicu dari stressor.

\section{Stres}

\section{A. Definsi stres}

Stres adalah inefisiensi seseorang dalam menghadapi suatu bahaya yang dihadapi oleh fisik, emosional, mental, dan spiritual manusia yang bisa mempengaruhi kesehatan fisik seseorang dalam jangka waktu yang lama. Menurut WHO stres adalah respon tubuh terhadap stressor beban hidup dan tekanan mental.

B. Sumber stress (stressor)

Ada beberapa sumber dasar pemicu stress yaitu
a. Lingkungan 
Lingkungan dapat memicu stress karena sangat berpengaruh terhadap perilaku kita dan memaksa kita untuk menyesuaikan diri. Contoh dari stressor lingkungan adalah perumahan yang rawan kejahatan, lingkungan yang toxic, cuaca yang panas, kebisingan, dan polusi udara.

b. Stressor social

Stress dapat ditimbulkan dari hubungan sosial dan tekanan sosial yang kita tempati. Hubungan dengan orang tua, pasangan, masyarakat, pekerjaan, dan sekolah. Contoh dari stressor sosial adalah perbedaan pendapat, prestasi yang didapat, besarnya pendapatan, dan kepergian orang yang dicintai.

c. Fisiologis

Stressor fisiologi merupakan stressor yang bersumber dari tidak normalnya keadaan fisik kita seperti sakit, lambatnya pertumbuhan, dan kecelakaan.

d. Pikiran

Pikiran negatif yang terlalu berlebihan dapat menjadi stressor karena pikiranlah yang menentukan masalah yang muncul.

C. Faktor-faktor stres

Faktor stres dapat dilihat dalam beberapa teori. Dan berbagai teori memiliki prespektif yang berbeda pula terhadaf factor penyebab stres. Di bawah ini akan dijelaskan beberapa prespektif yang ada

a. Prespektif Psikodinamik

Prespektif Psikodinamik menyebutkan bahwa penyebab stres terjadi karena adanya emosi yang menimbulkan essensial hypertension.

b. Prespektif biologis

Salah satu Prespektif biologis adalah somatic weakness model. prespektif ini meyakini bahwa faktor stes dipengaruhi oleh lemahnya organ tubuh karena keturunan dan penyakit yang masuk kedalam organ tubuh yang mengakibatkan mempunyai daya tahan yang lemah daripada organ yang lain. Dan menyebabkanya lebih rentan terhadap kerusakan ketika tidak dalam kondisi yang normal.

c. Prespektif kognitif dan perilaku 
Perspektif ini menekakan pada bagaimana cara seseorang melihat dan menilai mengenai ancaman yang terjadi dari luar. Seluruh prespektif seseorang dapat menimbulkan aktivitas simpatetik dan pengeluaran hormon stres. Timbulnya emosi negatif dapat menyebabkan tidak berfungsinya sistem ini dan dapat menyebabkan penyakit. Cara seseorang mengatasi emosinya ternyata berhubungan dengan penyakit hipertensi.

\section{Manajemen stres menghadapi Covid-19 dalam pendidikan Islam}

Tidak semua stres dinilai buruk bagi seseorang. Stres bisa dibagi dua yaitu stres baik dan stres buruk. Stres dikatakan baik jika bisa menimbulkan motivasi yang positif bagi diri sendiri. Tetapi jika tidak dapat menimbulkan motivasi maka akan disebut stres yang buruk, yang harus dihilangkan dari diri seseorang. Sedangkan stres yang ditimbulkan oleh adanya virus Covid-19 termasuk kedalam stres yang buruk. Itu dikarenakan dapat mempengarungi kesehatan seseorang. Misalnya jika kita stres dalam menghadapi Covid-19 ini maka imun yang ada di dalam tubuh kita akan menurun akibatnya resiko terhadap tertularnya virus Covid-19 akan lebih tinggi. Maka dari itu diperlukan adanya manajemen stres dalam menghadapi Covid-19 ini. Dalam pendidikan Islam pada saat pandemi Covid-19 stres terjadi akibat adanya sistem pembelajaran daring. Hal ini sangat berpengaruh terhadap pelajar maupun yang mengajar. Meraka terpaksa untuk belajar melalui media online. Ada beberapa sebagian orang mengeluh karena beberapa hal seperti, tugas yang diberikan terlalu berat, jaringan internet yang sulit, serta terbatasnya pengajar menyampaikan pelajaranya sehingga terjadi kesalah pahaman. Hal ini mengakibatkan beberapa orang merasa stres. Covid-19 ternyata tidak hanya menyerang fisik saja. Covid-19 ini bisa menyerang kesehatan mental seseorang. Oleh karena itu kita harus membentengi diri kita dengan ketrampilan mengolah stress. Setelah mengkaji beberapa literatur-literatur, manajemen stres dalam menghadapi Covid-19 ini ada beberapa cara yaitu:

1. Mempelajari apa yang menyebabkan stres

Saat ini informasi-informasi terkait covid-19 banyak tersebar dimedia sosial. Padahal informasi-informasi tersebut belum jelas kebenarannya. Ini mengakibatkan kepanikan pada sebagian orang. Maka dari itu kita harus mengelola informasi yang masuk dan sebisa mungkin menghindari hoax dengan membatasi diri hanya 
menerima informasi dari sumber yang terpercaya seperti WHO, kementrian kesehatan dan pemerintah.

2. Mengelola psikologis diri sendiri

Misalkan :

a) Membatasi diri menerima informasi tentang Covid-19 dan hanya menerima informasi dari sumber terpercaya. Hindari berita hoax yang membuat panic.

b) Berusaha melakukan upaya pencegahan dan kebersihan agar dapat menghilangkan rasa cemas. ${ }^{6}$

c) Berjemur dibawah sinar matahari dengan menghirup udara dan merasakan kehangatan matahari akan membuat imun semakin kuat.

3. Berpikir positif

Seperti :

a) Berpikir positif dan bertawakal kepada Allah dengan mengikuti upaya yang dianjurkan untuk mencegah penularan Covid-19.

b) Berpikir positif dengan adanya himbauan dirumah aja kita mempunyai waktu yang lebih banyak untuk beribadah kepada Allah serta waktu berkumpul dengan keluarga.

c) Berpikir positif bahwa setiap hal yang terjadi sudah ditakdirkan oleh Allah dan pasti ada hikmah yang baik di dalamnya.

d) Harus tetap produktif, jangan malas, dan tidak membuang-buang waktu untuk berrpikiran yang negatif.

e) Tetap melakukan silahturrahmi melalui media sosial, video call, dan harus saling menyemangati satu sama lain.

f) Lebih mendekatkan diri kepada Allah agar hati menjadi tenang. ${ }^{7}$

Adapun strategi dalam manajemen stress yaitu:

a) Strategi Fisik

\footnotetext{
${ }^{6}$ Psikolog Dr. H. Fakhrur Razi, MS Vetty Yulianty P, S.Si, MPH Syahidah Asma Amani, S.Gz Jimny Hilda Fauzia, M.Psi, Covid-19 : Buku Kesehatan Mandiri Untuk Sahabat (Depok: PD Prokami, 2020).

${ }^{7}$ Dr. H. Fakhrur Razi, MS Vetty Yulianty P, S.Si, MPH Syahidah Asma Amani, S.Gz Jimny Hilda Fauzia, M.Psi.
} 
b) Yaitu menenangkan diri misalnya, dengan relaksasi dan meditasi. Mengistirahatkan diri dari berbagai persoalan Covid-19

c) Strategi emosional

Yaitu dengan strategi menurunkan emosi negatif yang terdapat di dalam diri individu itu sendiri. Dengan menghilangkan emosi negatif tentang Covid-19. Emosi negatif yang tidak terkontrol dapat menyebabkan kecerobohan dalam bertindak.

d) Strategi kognitif

Yaitu dengan berpikir positif terhadap hal-hal yang sedang dialaminya. Berpikiran positif dengan Covid-19 bahwa terdapat hikmah yang baik didalamnya. Covid-19 memberikan dampak positif seperti berkumpulnya keluarga yang arang berkumpul untuk saling mencurahkan kasing sayang.

e) Strategi social

Yaitu dengan bersosialisasi pada lingkungan yang positif yang memberi motivasi dan dukungan kepada individu itu sendiri. ${ }^{8}$ saling memberi dukungan lewat media online dan menyemangati satu sama lainnya. Masyarakat yang masuk dalah ekonomi tinggi diharapkan dapat membantu masyarakat yang ekonomi rendah untuk bertahan.

\section{KESIMPULAN}

Manajemen stres dipengaruhi oleh pikiran. Oleh karena itu kita harus berpikir positif terhadap segala hal yang terjadi kepada kita. Stres terbagi menjadi dua yaitu stress baik dan stres buruk. Dan dalam menghadapi Covid-19 ini kita mengalami stres maka bisa digolongkan kedalam stres yang buruk. Dibalik dampak negatif Covid-19, ternyata ada beberapa hikmah yang bisa diambil. Jika kita berpikir positif maka energi yang kita keluarkan untuk orang-orang disekeliling kita akan positif juga. Ini bisa menyalurkan energi positif itu pada orang-orang agar bisa memanajemen stres dan mampu menjaga imun dengan baik agar terhindar dari Covid-19. Wabah Covid-19 menyebabkan banyak perubahan diberbagai kehidupan keseharian masyarakat. Hal ini harus disikapi secara rasional agar dapat bertahan hidup dan dapat saling membantu antar sesama untuk

\footnotetext{
${ }^{8}$ Segarahayu.
} 
bertahan. Penerapan protokol kesehatan yang dianjurkan pemerintah harus kita upayakan agar dapat mencegah penyebaran wabah Covid-19.

\section{DAFTAR PUSTAKA}

Agoes, and dkk. Teori Dan Manajemen Stres (Kontemporer Dan Islam). Malang: Taroda, 2003.

Arizal, Ardi Sahrul, Alda Rizka Fatkhia, Cut Zahiya Listy Humairah, Arif Sugianto, Muhammad Aziz Umar, and Isma Yulia. "Pendidikan Akidah Akhlak Dengan Metode Brain Based Learning." BELAJEA: Jurnal Pendidikan Islam 4, no. 1 (2019): 61. https://doi.org/10.29240/belajea.v4i1.767.

Barry, Mazin, Maha Al Amri, and Ziad A. Memish. 2020. "COVID-19 in the Shadows of MERS-CoV in the Kingdom of Saudi Arabia." Journal of Epidemiology and Global Health 10(1):1-3.

Cortegiani, Andrea, Giulia Ingoglia, Mariachiara Ippolito, Antonino Giarratano, and Sharon Einav. 2020. "A Systematic Review on the Efficacy and Safety of Chloroquine for the Treatment of COVID-19.” Journal of Critical Care 3-7.

Dauyah, Ema, Ema Dauyah, Universitas Abulyatama, and Aceh Besar. "Jurnal Serambi Ilmu, Volume 19, Nomor 2, Edisi September 2018.” Serambi Ilmu 19, no. 2 (2018): 274-90.

Dr. H. Fakhrur Razi, MS Vetty Yulianty P, S.Si, MPH Syahidah Asma Amani, S.Gz Jimny Hilda Fauzia, M.Psi, Psikolog. Covid-19: Buku Kesehatan Mandiri Untuk Sahabat. Depok: PD Prokami, 2020.

Handayani, Astuti Budi, and Suyadi Suyadi. "Relevansi Konsep Akal Bertingkat Ibnu Sina Dalam Pendidikan Islam Di Era Milenial." Ta'dibuna: Jurnal Pendidikan Islam 8, no. 2 (2019): 222-40. https://doi.org/10.32832/TADIBUNA.V8I2.2034.

Hanum, Lathifah, Dini P. Daengsari, and Cut Nurul Kemala. "Penerapan Manajemen Stres Berkelompok Dalam Menurunkan Stres Pada Lanjut Usia Berpenyakit Kronis.” Jurnal Psikologi 43, no. 1 (2016): 42. https://doi.org/10.22146/jpsi.11501 
Hariyati, Rr. Tutik Sri, Made Sumarwati, and Hanny Handiyani. "Pengaruh Manajemen Stres Terhadap Kesiapan Pasien Stroke Dan Keluarga Dalam Merencanakan Perilaku Adaptif Pasca Perawatan Di Rumah Sakit.” Jurnal Keperawatan Indonesia 8, no. 1 (2014): 13-17. https://doi.org/10.7454/jki.v8i1.141.

Hawari, Dadang. Manajemen Stres Cemas Dan Depresi. Balai Penerbit FKUI, 2011.

Jum'ati, Nurleila, and Himmayatul Wusma. "Stres Kerja (Occupational Stres) Yang Mempengaruhi Kinerja Individu Pada Dinas Kesehatan Bidang Pencegahan Pemberantasan Penyakit Dan Penyehatan Lingkungan (P2P-PL) Di Kabupaten Bangkalan.” Jurnal NeO-Bis 7, no. 2 (2013): 1-17.

Maharaj, Savi, and Adam Kleczkowski. 2012. "Controlling Epidemic Spread by Social Distancing: Do It Well or Not at All.” BMC Public Health 12:679.

Peeri, Noah C, Nistha Shrestha, Siddikur Rahman, Zhengqi Tan, Saana Bibi, and Mahdi Baghbanzadeh. "OUP Accepted Manuscript." International Journal of Epidemiology, 2020, 1-10. https://doi.org/10.1093/ije/dyaa033.

Rais, Amin, and Pengembangan Kecerdasan Spiritual. "E-ISSN: 2540-8348 p-ISSN: 20883390 Amin Rais, Dkk., Pengembangan Kecerdasan Spiritual” 09, no. 02 (n.d.): 13153.

Segarahayu, Rizky Dianita. "Pengaruh Manajemen Stres Terhadap Penurunan Tingkat Stres Pada Narapidana Di Lpw Malang.” Universitas Negeri Malang, 2013, 1-16. http://jurnalonline.um.ac.id/data/artikel/artikelDEB288149FBAA98C9CB27EB18035D95A.pdf.

Stress, A Pengertian. “Management Stress (Manajemen Stres).” Manajemen Stress, 2008.

“Stres Kerja Pada Perawat Instalasi Gawat Darurat Di RSUD Pasar Rebo Tahun 2014." Jurnal Administrasi Rumah Sakit Indonesia, 2014. https://doi.org/10.1234/arsi.v1i2.2176. 
Sohrabi, Catrin, Zaid Alsafi, Niamh O'Neill, Mehdi Khan, Ahmed Kerwan, Ahmed AlJabir, Christos Iosifidis, and Riaz Agha. 2020. "World Health Organization Declares Global Emergency: A Review of the 2019 Novel Coronavirus (COVID-19)." International Journal of Surgery 76(February):71-76.

Suyadi, Suyadi. 2018. "Diferensiasi Otak Laki-Laki Dan Perempuan Guru Taman KanakKanak Aisyiyah Nyai Ahmad Dahlan Yogyakarta: Studi Pendidikan Islam Anak Usia Dini Perspektif Gender Dan Neurosains.” Sawwa: Jurnal Studi Gender 13(2):179.

Suyadi. "Mainstreaming the Knowledge of Islamic Education With Progress and of Islam Nusantara Education.” Akademika 24, no. 1 (2019): 37-66.

Suyadi. Teori Pembelajaran Anak Usia Dini Dalam Kajian Neurosains. Bandung: Rosda Karya, 2016.

Suyadi, Suyadi. n.d. "The Synergy of Arts, Science, and Islam in Early Childhood Learning in Yogyakarta.” TARBIYA: Journal of Education in Muslim Society 5(1):30-42.

Suyadi. 2017. "Pendidikan Islam Dan Neurosains.” Pp. 8-9 in Vol. 6.

Suyadi. 2019. Pengantar Neurosains Pendidikan Islam. Yogyakarta: UAD PRESS

Tian, Sijia, Nan Hu, Jing Lou, Kun Chen, Xuqin Kang, Zhenjun Xiang, Hui Chen, Dali Wang, Ning Liu, Dong Liu, Gang Chen, Yongliang Zhang, Dou Li, Jianren Li, Huixin Lian, Shengmei Niu, Luxi Zhang, and Jinjun Zhang. 2020. "Characteristics of COVID-19 Infection in Beijing." Journal of Infection 80(4):401-6.

Uscher-Pines, Lori, Heather L. Schwartz, Faruque Ahmed, Yenlik Zheteyeva, Erika Meza, Garrett Baker, and Amra Uzicanin. "School Practices to Promote Social Distancing in K-12 Schools: Review of Influenza Pandemic Policies and Practices." BMC Public Health 18, no. 1 (2018): 1-13. https://doi.org/10.1186/s12889-018-5302-3.

Wilder-Smith, A., and D. O. Freedman. "Isolation, Quarantine, Social Distancing and Community Containment: Pivotal Role for Old-Style Public Health Measures in the Novel Coronavirus (2019-NCoV) Outbreak." Journal of Travel Medicine 27, no. 2 (2020): 1-4. https://doi.org/10.1093/jtm/taaa020. 
Wulandari, Apri, and Suyadi Suyadi. "Pengembangan Emosi Positif Dalam Pendikan Islam Perspektif Neurosains." Tadrib: Jurnal Pendidikan Agama Islam 5, no. 1 (2019): 5167. https://doi.org/10.19109/tadrib.v5i1.3016.

Xu, Chunwen, Xilian Luo, Chuck Yu, and Shi Jie Cao. "The 2019-NCoV Epidemic Control Strategies and Future Challenges of Building Healthy Smart Cities." Indoor and Built Environment, 2020. https://doi.org/10.1177/1420326X20910408. 